Hispanic Methodists, Presbyterians, and Baptists in Texas 


\section{Number Eighteen}

Jack and Doris Smothers Series in Texas History, Life, and Culture 


\section{HISPANIC METHODISTS, PRESBYTERIANS, AND BAPTISTS IN TEXAS}

Paul Barton

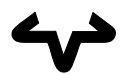

University of Texas Press Austin 
Publication of this work was made possible in part by support from the J. E. Smothers, Sr., Memorial Foundation and the National Endowment for the Humanities.

Copyright (C) 2006 by the University of Texas Press

All rights reserved

Printed in the United States of America

First edition, 2006

Requests for permission to reproduce material from this work should be sent to:

Permissions

University of Texas Press

P.O. Box 7819

Austin, TX 78713-7819

www.utexas.edu/utpress/about/bpermission.html

@ The paper used in this book meets the minimum requirements of ANSI/NISO Z39.48-1992 (R1997) (Permanence of Paper).

Library of Congress Cataloging-in-Publication Data

Barton, Paul, 1961-

Hispanic Methodists, Presbyterians, and Baptists in Texas / Paul Barton.1st ed.

p. $\quad \mathrm{cm}$. - (Jack and Doris Smothers series in Texas history, life, and culture ; no. 18)

Includes bibliographical references and index.

ISBN-13: 978-0-292-71291-1 (cloth : alk. paper)

ISBN-10: 0-292-71291-X (cloth : alk. paper)

ISBN-13: 978-0-292-71335-2 (pbk. : alk. paper)

ISBN-10: 0-292-71335-5 (pbk. : alk. paper)

1. Hispanic Americans-Texas-Religion. 2. Church work with Hispanic Americans. 3. Texas-Church history. I. Title. II. Series.

BR563.H57B37 2006

$280^{\prime} .408968073-\mathrm{dc} 22$

2005034965 
For my wife, Beth, and my daughter, Elisa 
THIS PAGE INTENTIONALLY LEFT BLANK 